\title{
BRIEF COMMUNICATION Cross-cultural adaptation of the Revised Neurophysiology of Pain Questionnaire into Brazilian Portuguese language
}

\author{
Adaptação transcultural do Questionário Neurofisiológico \\ da Dor revisado para língua portuguesa do Brasil
}

Leandro Alberto Calazans Nogueira', Aline de Oliveira Chaves², Nathalia Oliveira ${ }^{3}$, Renato Santos de Almeida4, Felipe José Jandre Reis ${ }^{5}$, Fernanda Guimarães de Andrade ${ }^{6}$, Mark Jon Catley

\begin{abstract}
Objective: To perform a cross-cultural adaptation of the Neurophysiology of Pain Questionnaire for the Brazilian population (NPQ-BR). Methods: A translation and cross-cultural adaptation study were conducted in 11 stages according to standard procedures. Descriptive and inferential statistics were performed. The internal consistency of the questionnaire was assessed using Cronbach's Alpha test (a). Results: Four translators, six experts, twenty-one patients and ten physiotherapists participated in the study. The NPQ-BR was obtained after seven versions. The expert committee adapted four out of twelve items (item 1, 3, 11, and 12) to adapt the content of the instrument to the Brazilian context. The pre-test phase showed good internal consistency $(a=0.63)$. The comparison of the correct answers of the questionnaire between the groups (physical therapist group mean $=7.0 \pm 1.7$; patient group mean $=3.7 \pm 2.1 ; p<0.01)$ confirmed the discriminative validity of the NPQ-BR. Conclusion: The Neurophysiology of Pain Questionnaire was cross-culturally adapted into a Brazilian context and can be used to assess the level of neurophysiological knowledge of pain of Brazilian patients. The interpretation of the results of the NPQ-BR must be taken with caution due to the absence of a robust validation methodology of the instrument.
\end{abstract}

\section{Keywords}

Pain, rehabilitation,

validation studies,

cognitive neuroscience, psychometrics.

\section{RESUMO}

Objetivo: Realizar a adaptação transcultural do Questionário Neurofisiológico de Dor (QND) para a população brasileira. Métodos: Um estudo de tradução e adaptação transcultural foi conduzido em 11 estágios de acordo com procedimentos padronizados. Foi realizada estatística descritiva e inferencial. A consistência interna do questionário foi avaliada pelo teste de Alfa de Cronbach (a). Resultados: Participaram do estudo quatro tradutores, seis especialistas, vinte e um pacientes e dez fisioterapeutas. A versão brasileira do QND foi ob-

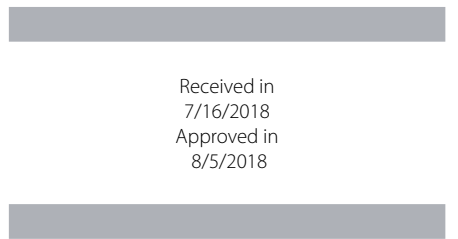

DOI: $10.1590 / 0047-2085000000215$
1 Rio de Janeiro Federal Institute (IFRJ), Physiotherapy Department; University Centre Augusto Motta (Unisuam), Postgraduate Progam of Reabilitation Science, Rio de Janeiro, RJ, Brazil.

2 Physical Therapy, Rio de Janeiro, RJ, Brazil.

3 University Centre Augusto Motta (Unisuam), Postgraduate Progam of Reabilitation Science, Rio de Janeiro, RJ, Brazil.

4 University Centre Serra dos Órgãos (Unifeso), Hospital Universitário Gaffrée e Guinle, Physical Therapy, Rio de Janeiro, RJ, Brazil.

5 Rio de Janeiro Federal Institute (IFRJ), Physiotherapy Department; Universidade Federal do Rio de Janeiro (UFRJ), Clinical Medicine Department, Postgraduation Progam, Rio de Janeiro, RJ, Brazil.

6 Rio de Janeiro Federal Institute (IFRJ), Physiotherapy Department, Rio de Janeiro, RJ, Brazil.

7 University of South Australia, Sansom Institute for Health Research, Adelaide, Australia. 


\section{Palavras-chave}

Dor, reabilitação, estudos

de validação, neurociência

cognitiva, psicometria. tida após sete versões. O comitê de especialistas adaptou quatro dos doze itens (item 1, 3, 11 e 12) para ajustar o conteúdo do instrumento ao contexto brasileiro. A fase de pré-teste evidenciou boa consistência interna $(a=0,63)$. A comparação dos acertos dos itens do questionário entre os grupos (média dos fisioterapeutas $=7,0 \pm 1,7$; média dos pacientes $=3,7 \pm$ 2,1; $p<0,01)$ confirmou a validade discriminativa da versão brasileira do QND. Conclusão: O Questionário Neurofisiológico de Dor revisado foi adaptado para o contexto brasileiro e pode ser utilizado para avaliar o nível de conhecimento neurofisiológico da dor de pacientes brasileiros. A interpretação dos resultados da versão brasileira do QND deve ser feita com cautela devido à ausência de metodologia robusta de validação do instrumento.

\section{INTRODUCTION}

Pain is an extremely prevalent symptom. The Brazilian National Survey showed that $43.2 \%$ of the general population has some musculoskeletal disorder ${ }^{1}$. In addition, chronic pain affects approximately $40 \%$ of the population globally². Thus, chronic pain is a significant problem, which has been seen as a major public healthcare problem ${ }^{3}$. Patients with chronic musculoskeletal pain presented pain relief, improving functionality, reduced psychosocial factors, in addition to the improvement of the patient knowledge of pain after a program of pain neuroscience education ${ }^{4}$.

The approach focused on the neurophysiological knowledge of pain demonstrate clinical benefits for patients with musculoskeletal pain. Pain education is a strategy that aims teach people with pain about the neurophysiological and neurobiological process involved in the pain experience, especially in the chronic pain ${ }^{5}$. Educational interventions developed to explain pain are based on a modern understanding of pain and have been shown to be effective. Reconceptualizing pain through education is thought to alter attitudes and beliefs related to pain ${ }^{6,7}$, reduce catastrophising and increase physical performance ${ }^{7}$. The combination of pain education with conventional therapy is associated with pain and disability improvement in many populations s,8-10. $^{6}$.

The Neurophysiology of Pain Questionnaire (NPQ) was developed as a method of assessing whether health professionals and patients can understand the complex neurophysiological mechanisms that underpin pain ${ }^{11}$. The NPQ has been used in clinical trials to monitor knowledge change in educational interventions ${ }^{6,7,11}$ and is widely used by clinicians ${ }^{12}$. The NPQ has been translated into several languages but has not been used in the Brazilian population, despite of the remarkable growing of the Brazilian scientific production ${ }^{13}$. The aim of the current study was to perform a cross-cultural adaptation of the NPQ for the Brazilian population.

\section{METHODS}

\section{Neurophysiology of Pain Questionnaire}

The NPQ is a self-administered instrument that was originally developed with nineteen items related to pain neuro- physiology ${ }^{11}$. Each item has the following response options: true, false and undecided. A recent study investigated the psychometric properties of English version of the NPQ and noted several of the items were redundant or functioned poorly. It was thus postulated that a twelve-item revised NPQ would function superiorly to the original questionnaire and be less burdensome ${ }^{12}$. For this reason, the revised NPQ was translated into Brazilian Portuguese.

\section{Study design}

A translation and cross-cultural adaptation study was conducted in accordance with the recommendations of Wild et al. ${ }^{14}$. Ethics approval was provided by Hospital Universitário Gaffrée e Guinle (HUGG) Human Research Ethics Committees. All subjects provided informed consent prior to their participation.

\section{Procedures and participants}

The scale was first sent to two forward translators after receiving permission from the questionnaire's author ${ }^{11}$. The 12 item revised $\mathrm{NPQ}^{12}$ was translated from English into Brazilian Portuguese by one native English translator (fluent in English language and experienced in translation; American citizen; T1) and one native Portuguese translator (with academic and professional experience in translation, Brazilian citizen; T2). The reconciliation stage was performed by the translators and the authors of the study whereby the two forward translations were merged into a single forward translation version through discussion (T12).

The reconciled version was then sent to two independent back-translators with the same credentials as the forward translators but who were not involved in the initial translation phase. These two translators were unaware of the English version of the questionnaire. The harmonization phase was conducted by the all translators and the authors of the study and any discrepancies between the English version and its derivative translations were resolved through discussion.

The expert committee compared the content of the harmonized version to the original English version and was asked to suggest modifications and corrections, explaining their reasoning. The intention of this stage was to ensure 
the NPQ was adapted to the Brazilian context, maintained simple language, improved understanding of the items and increased its clarity. A corrected version was produced for pre-testing.

A patient group and a health professional group participated in the pre-test phase. Twenty patients with musculoskeletal disorders were recruited by convenience from the physiotherapy department of HUGG, Rio de Janeiro, Brazil. The patients were eligible for inclusion if they were over 18 years of age and had experienced ongoing pain for greater than six months, independent of clinical diagnosis. Patients with cognitive impairment or who could not read and speak Brazilian Portuguese were excluded from the study. The health professional group comprised of 10 physiotherapists from the HUGG physiotherapy service, each with a minimum of 5 years' experience in musculoskeletal disorders. The physiotherapists have neurophysiology disciplines in their formation, including neurophysiology of pain. Therefore, it was assumed that the NPQ would be able to differentiate between those with and without physiology of pain knowledge (i.e., physiotherapists versus patients with musculoskeletal pain). In this study, discriminative validity was evaluated by comparing mean values from the Neurophysiology of Pain Questionnaire (NPQ) total score for physiotherapists compared to patients with musculoskeletal pain.

The questionnaire was self-administered and, after answering the pre-testing version, each subject was interviewed by the researcher about their understanding of the items and suggestions for improvement to the questionnaire. Participants in each stage are described in figure 1 .

\section{Statistical analysis}

Descriptive statistics were calculated using Statistical Package for Social Sciences (SPSS - version 22). The pre-test data obtained from the patients and clinicians was compared to establish discriminative validity. Normality of the distribution was established using the Shapiro Wilk test and a student t-test with alpha set at 0.05 was used to compare the two groups. The data were then pooled and the internal consistency of the questionnaire was assessed using Cronbach's Alpha test.

\section{RESULTS}

The translation stage produced two independent versions ( $\mathrm{T} 1$ and $\mathrm{T} 2$ ) that were reconciled (T12). The back translation step also produced two independent versions (BT1 and BT2) and after the reconciliation it was created a single version (BT12). The items presented similar translations without the need for adjustments in the literal equivalence.
The reconciled version was sent to the expert committee. After reviewing the comments and suggestions of the expert committee, it was obtained consensus on various items, and a single version was produced with some recommendations (EV). The expert committee adapted four out of twelve items (item 1, 3, 11, and 12) to adapt the content of the instrument to the Brazilian context. All suggestions were described at the end of the questionnaire and pre-test participants were asked to express their opinion on the best way of understanding each item. Some modifications were necessary to meet the equivalent idiomatic, taking into account the conceptual equivalence. It was changed "ter" to "sentir" as well as "transmitem" to "levam". Some expert committee members suggested the translational modification "injured" of "lesionado" to "machucado", aimed at better understanding of the participants, but this adaptation was discarded after the pretest. The final result of the translation process and cross-cultural adaptation of the Brazilian NPQ is presented in table 1.

Regardless of the accuracy of their responses, all of the participants confirmed that they understood all of the questions, suggesting that the cross-cultural adaption was successful.

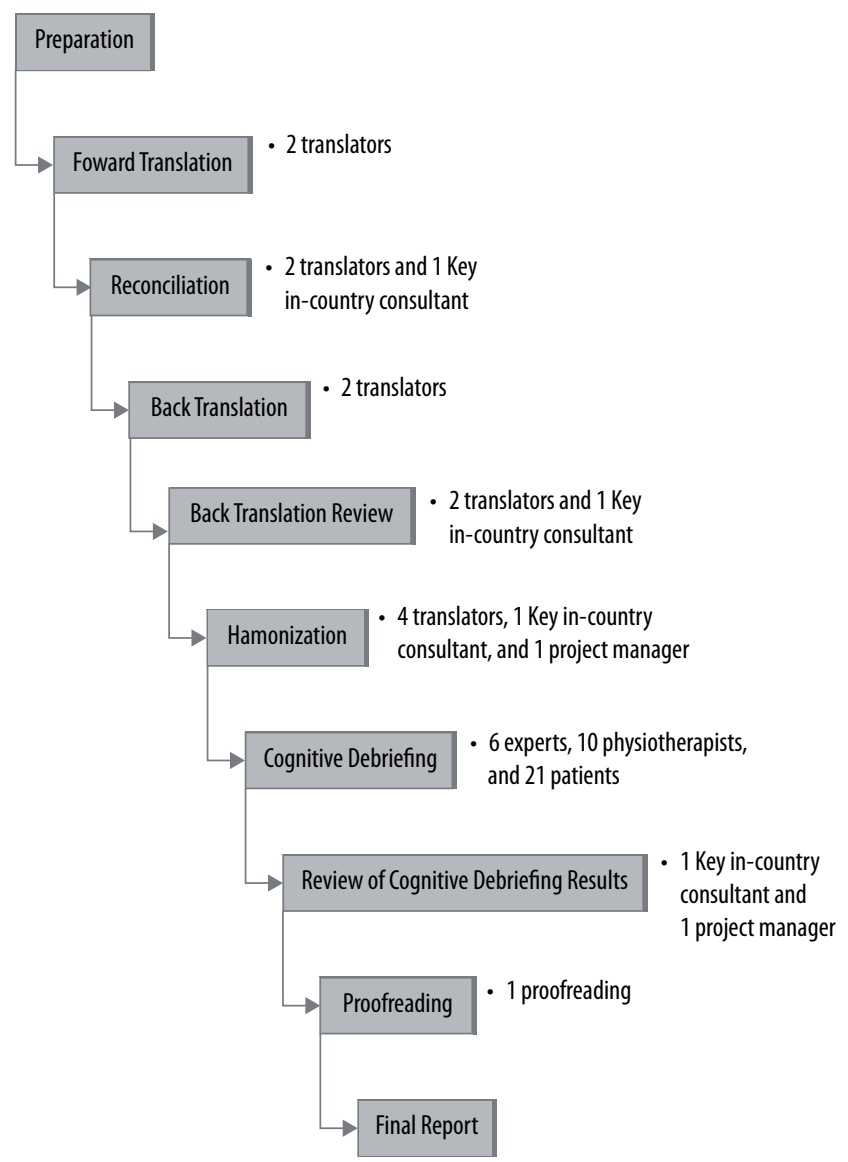

Figure 1. Flowchart with stages and participants of the study. 
Table 1. Neurophysiology of Pain Questionnaire translation process modification

\begin{tabular}{|c|c|c|c|c|}
\hline Item & Original version & Translation version (V12) & Experts version (EV) & Final version \\
\hline 1 & $\begin{array}{l}\text { When part of your body is injured, special } \\
\text { pain receptors convey the pain message } \\
\text { to your brain. }\end{array}$ & $\begin{array}{l}\text { Quando parte do seu corpo está } \\
\text { lesionado, receptores especiais da dor } \\
\text { transmitem a mensagem da dor para } \\
\text { seu cérebro. }\end{array}$ & $\begin{array}{l}\text { Quando parte do seu corpo está } \\
\text { lesionado, receptores especiais da dor } \\
\text { transmitem a mensagem da dor para } \\
\text { seu cérebro. }\end{array}$ & $\begin{array}{l}\text { Quando parte do seu corpo está } \\
\text { lesionado, receptores especiais da dor } \\
\text { levam a mensagem da dor para seu } \\
\text { cérebro. }\end{array}$ \\
\hline 2 & $\begin{array}{l}\text { Pain only occurs when you are injured or } \\
\text { at risk of being injured. }\end{array}$ & $\begin{array}{l}\text { Dor somente ocorre quando você está } \\
\text { lesionado ou correndo risco de ser } \\
\text { lesionado. }\end{array}$ & $\begin{array}{l}\text { Dor somente ocorre quando você está } \\
\text { lesionado ou está correndo risco de se } \\
\text { lesionar. }\end{array}$ & $\begin{array}{l}\text { Dor somente ocorre quando você está } \\
\text { lesionado ou está correndo risco de se } \\
\text { lesionar. }\end{array}$ \\
\hline 3 & $\begin{array}{l}\text { Special nerves in your spinal cord convey } \\
\text { danger messages to your brain. }\end{array}$ & $\begin{array}{l}\text { Nervos especiais na sua medula espinhal } \\
\text { transmitem mensagens de perigo para } 0 \\
\text { seu cérebro. }\end{array}$ & $\begin{array}{l}\text { Nervos especiais na sua medula espinhal } \\
\text { transmitem mensagens de perigo para } 0 \\
\text { seu cérebro. }\end{array}$ & $\begin{array}{l}\text { Nervos especiais na sua medula espinhal } \\
\text { levam mensagens de perigo para o seu } \\
\text { cérebro. }\end{array}$ \\
\hline 4 & Pain occurs whenever you are injured. & $\begin{array}{l}\text { Dor ocorre sempre que você está } \\
\text { lesionado. }\end{array}$ & $\begin{array}{l}\text { Dor ocorre sempre que você está } \\
\text { lesionado. }\end{array}$ & $\begin{array}{l}\text { Dor ocorre sempre que você está } \\
\text { lesionado. }\end{array}$ \\
\hline 5 & $\begin{array}{l}\text { The brain decides when you will } \\
\text { experience pain. }\end{array}$ & $\begin{array}{l}0 \text { cérebro decide quando você vai sentir } \\
\text { dor. }\end{array}$ & $\begin{array}{l}0 \text { cérebro decide quando você vai sentir } \\
\text { dor. }\end{array}$ & $\begin{array}{l}0 \text { cérebro decide quando você vai sentir } \\
\text { dor. }\end{array}$ \\
\hline 6 & $\begin{array}{l}\text { Nerves adapt by increasing their resting } \\
\text { level of excitement. }\end{array}$ & $\begin{array}{l}\text { Os nervos se adaptam aumentando seu } \\
\text { nível de excitabilidade em repouso. }\end{array}$ & $\begin{array}{l}\text { Os nervos se adaptam aumentando seu } \\
\text { nível de excitabilidade em repouso. }\end{array}$ & $\begin{array}{l}\text { Os nervos se adaptam aumentando seu } \\
\text { nível de excitabilidade em repouso. }\end{array}$ \\
\hline 7 & $\begin{array}{l}\text { Chronic pain means that an injury hasn't } \\
\text { healed properly. }\end{array}$ & $\begin{array}{l}\text { Dor crônica significa que uma lesão não } \\
\text { foi curada corretamente. }\end{array}$ & $\begin{array}{l}\text { Dor crônica significa que uma lesão não } \\
\text { foi curada corretamente. }\end{array}$ & $\begin{array}{l}\text { Dor crônica significa que uma lesão não } \\
\text { foi curada corretamente. }\end{array}$ \\
\hline 8 & $\begin{array}{l}\text { Worse injuries always result in worse } \\
\text { pain. }\end{array}$ & $\begin{array}{l}\text { Piores lesões sempre resultam em pior } \\
\text { dor. }\end{array}$ & $\begin{array}{l}\text { Piores lesões resultam sempre em pior } \\
\text { dor. }\end{array}$ & $\begin{array}{l}\text { Piores lesões resultam sempre em pior } \\
\text { dor. }\end{array}$ \\
\hline 9 & $\begin{array}{l}\text { Descending neurons are always } \\
\text { inhibitors. }\end{array}$ & $\begin{array}{l}\text { Neurônios descendentes são sempre } \\
\text { inibitórios. }\end{array}$ & $\begin{array}{l}\text { Neurônios descendentes são sempre } \\
\text { inibitórios. }\end{array}$ & $\begin{array}{l}\text { Neurônios descendentes são sempre } \\
\text { inibitórios. }\end{array}$ \\
\hline 10 & $\begin{array}{l}\text { When you injure yourself, the } \\
\text { environment you are in will not affect the } \\
\text { amount of pain you experience, as long } \\
\text { as the injury is exactly the same. }\end{array}$ & $\begin{array}{l}\text { Quando você se lesiona, } 0 \text { ambiente em } \\
\text { que você está não afetará a quantidade } \\
\text { de dor que você sente, desde que a lesão } \\
\text { seja exatamente a mesma. }\end{array}$ & $\begin{array}{l}\text { Quando você se lesiona, } 0 \text { ambiente em } \\
\text { que você está não afetará a quantidade } \\
\text { de dor que você sente, desde que a lesão } \\
\text { seja exatamente a mesma. }\end{array}$ & $\begin{array}{l}\text { Quando você se lesiona, } 0 \text { ambiente em } \\
\text { que você está não afetará a quantidade } \\
\text { de dor que você sente, desde que a lesão } \\
\text { seja exatamente a mesma. }\end{array}$ \\
\hline 11 & $\begin{array}{l}\text { It is possible to have pain and not know } \\
\text { about it. }\end{array}$ & É possível ter dor e não saber disso. & É possível ter dor e não saber disso. & É possível sentir dor e não saber disso. \\
\hline 12 & $\begin{array}{l}\text { When you are injured, special receptors } \\
\text { convey the danger message to your } \\
\text { spinal cord. }\end{array}$ & $\begin{array}{l}\text { Quando você está lesionado, receptores } \\
\text { especiais transmitem a mensagem de } \\
\text { perigo para a sua medula espinhal. }\end{array}$ & $\begin{array}{l}\text { Quando você está lesionado, receptores } \\
\text { especiais transmitem a mensagem de } \\
\text { perigo para a sua medula espinhal. }\end{array}$ & $\begin{array}{l}\text { Quando você está lesionado, receptores } \\
\text { especiais levam a mensagem de perigo } \\
\text { para a sua medula espinhal. }\end{array}$ \\
\hline
\end{tabular}

\section{Discriminative validity}

The comparison of the correct answers of the questionnaire between the groups (physical therapist group mean $=7.0 \pm$ 1.7; patient group mean $=3.7 \pm 2.1 ; p<0.01$ ) confirmed the discriminative validity of the Brazilian version of the NPQ.

\section{Internal consistency}

The internal consistency analysis revealed a reliability value of alpha $=0.63$.

\section{DISCUSSION}

The aim of the study was to perform a cross-cultural adaption of the NPQ for the Brazilian population. That all of the participants reported that they understood the questions asked of them suggests the adaption was successful. Preliminary data also suggest the Brazilian NPQ can discriminate those with higher and lower levels of knowledge as there was a significant difference between patient and clinician scores.
The internal consistency value observed ( $a=0.63$ Chronbach's) in the pre-test data analysed here was slightly lower than recommended in the literature. Meeus et al. ${ }^{15}$ completed the cross-cultural adaptation of the original 19 item NPQ to Dutch and found an internal consistency value slightly higher (Cronbach's $a=0.77$ ). Catley et al. ${ }^{12}$ reported a Person Separation Index (a Rasch analysis equivalent of Cronbach's alpha that can be interpreted in a similar manner) of 0.84 and 0.82 for the original 19 item English NPQ and revised 12 item NPQ respectively. However, both authors assessed significantly larger samples than assessed in this study and this difference probably accounts for the lower value of internal consistency observed here. In any case, these preliminary data should be replicated in an independent larger sample using the final Brazilian NPQ, such that a more comprehensive analysis of the questionnaires psychometric properties can be undertaken.

All participants understood the translated items in Brazilian Portuguese, despite having a low rate of correct answers in neurophysiological knowledge of pain. A small number of participants suggested modifications to the items 
to suit the level of education of the target population in the pretest. The low level of education may contribute to the low values of the correct answers.

Interestingly, physiotherapists recruited for the pretest also showed a low level of neurophysiological knowledge of pain. Meeus et al. ${ }^{15}$ also observed a low values of correct answers by health professionals even recruiting professionals who received at least 20 hours of pain neurophysiology during their education. Several authors have emphasized the need for education of health professionals to aspects of pain perception.

The marginal value observed in the reliability analysis probably reflects the low number of participants. Future research should investigate larger samples using a robust methodology as Item Response Theory and Rasch analysis. Further validation studies are needed to confirm our findings using a confirmatory factor analysis which is a more sophisticated method for validation analysis. Despite these caveats, we believe that our study provides useful contribution regarding the assessment of the pain neurophysiology for Brazilians which may improve the pain management.

\section{CONCLUSION}

The Neurophysiology of Pain Questionnaire was cross-culturally adapted into a Brazilian context and can be used to assess the level of neurophysiological knowledge of pain of Brazilian patients. The interpretation of the results of the Brazilian version of the NPQ must be taken with caution due to the absence of a robust validation methodology of the instrument.

\section{REFERENCES}

1. IBGE. Estatística. Pesquisa Nacional de Saúde - PNS 2013: percepção do estado de saúde, estilos de vida e doenças crônicas. Rio de Janeiro: IBGE; 2014.
2. Tsang A, Von Korff M, Lee S, Alonso J, Karam E, Angermeyer MC, et al. Common chronic pain conditions in developed and developing countries: gender and age differences and comorbidity with depression-anxiety disorders. J Pain. 2008;9(10):883-91.

3. Goldberg DS, McGee SJ. Pain as a global public health priority. BMC Public Health. 2011;11:770

4. Louw A, Zimney K, Puentedura EJ, Diener I. The efficacy of pain neuroscience education on musculoskeletal pain: a systematic review of the literature. Physiother Theory Pract. 2016;32(5):332-55

5. Louw A, Nijs J, Puentedura EJ. A clinical perspective on a pain neuroscience education approach to manual therapy. J Man Manip Ther. 2017;25(3):160-8.

6. Meeus M, Nijs J, Van Oosterwijck J, Van Alsenoy V, Truijen S. Pain physiology education improves pain beliefs in patients with chronic fatigue syndrome compared with pacing and self-management education: a double-blind randomized controlled trial. Arch Phys Med Rehabil. 2010;91(8):1153-9.

7. Moseley GL. Evidence for a direct relationship between cognitive and physical change during an education intervention in people with chronic low back pain. Eur J Pain. 2004:8(1):39-45

8. Ryan CG, Gray HG, Newton M, Granat MH. Pain biology education and exercise classes compared to pain biology education alone for individuals with chronic low back pain: a pilot randomised controlled trial. Man Ther. 2010;15(4):382-7.

9. Clarke CL, Ryan CG, Martin DJ. Pain neurophysiology education for the management of individuals with chronic low back pain: systematic review and meta-analysis. Man Ther. 2011;16(6):544-9.

10. Van Oosterwijck J, Nijs J, Meeus M, Truijen S, Craps J, Van den Keybus N, et al. Pain neurophysiology education improves cognitions, pain thresholds, and movement performance in people with chronic whiplash: a pilot study. J Rehabil Res Dev. 2011;48(1):43-58.

11. Moseley L. Unraveling the barriers to reconceptualization of the problem in chronic pain: the actual and perceived ability of patients and health professionals to understand the neurophysiology. J Pain. 2003;4(4):184-9.

12. Catley MJ, O'Connell NE, Moseley GL. How good is the neurophysiology of pain questionnaire? A Rasch analysis of psychometric properties. J Pain. 2013;14(8):818-27.

13. Furtado CA, Davis CA Jr., Gonçalves MA, Almeida JM. a spatiotemporal analysis of Brazilian science from the perspective of researchers' career trajectories. PLOS One. 2015;10(10):e0141528.

14. Wild D, Grove A, Martin M, Eremenco S, McElroy S, Verjee-Lorenz A, et al. Principles of Good Practice for the Translation and Cultural Adaptation Process for Patient-Reported Outcomes (PRO) Measures: report of the ISPOR Task Force for Translation and Cultural Adaptation. Value Health. 2005;8(2):94-104

15. Meeus M, Nijs J, Elsemans K, Truijen S, Meirleir K. Development and Properties of the Dutch Neurophysiology of Pain Test in Patients with Chronic Fatigue Syndrome. J Musculoskelet Pain. 2010;18(1):58-65. 